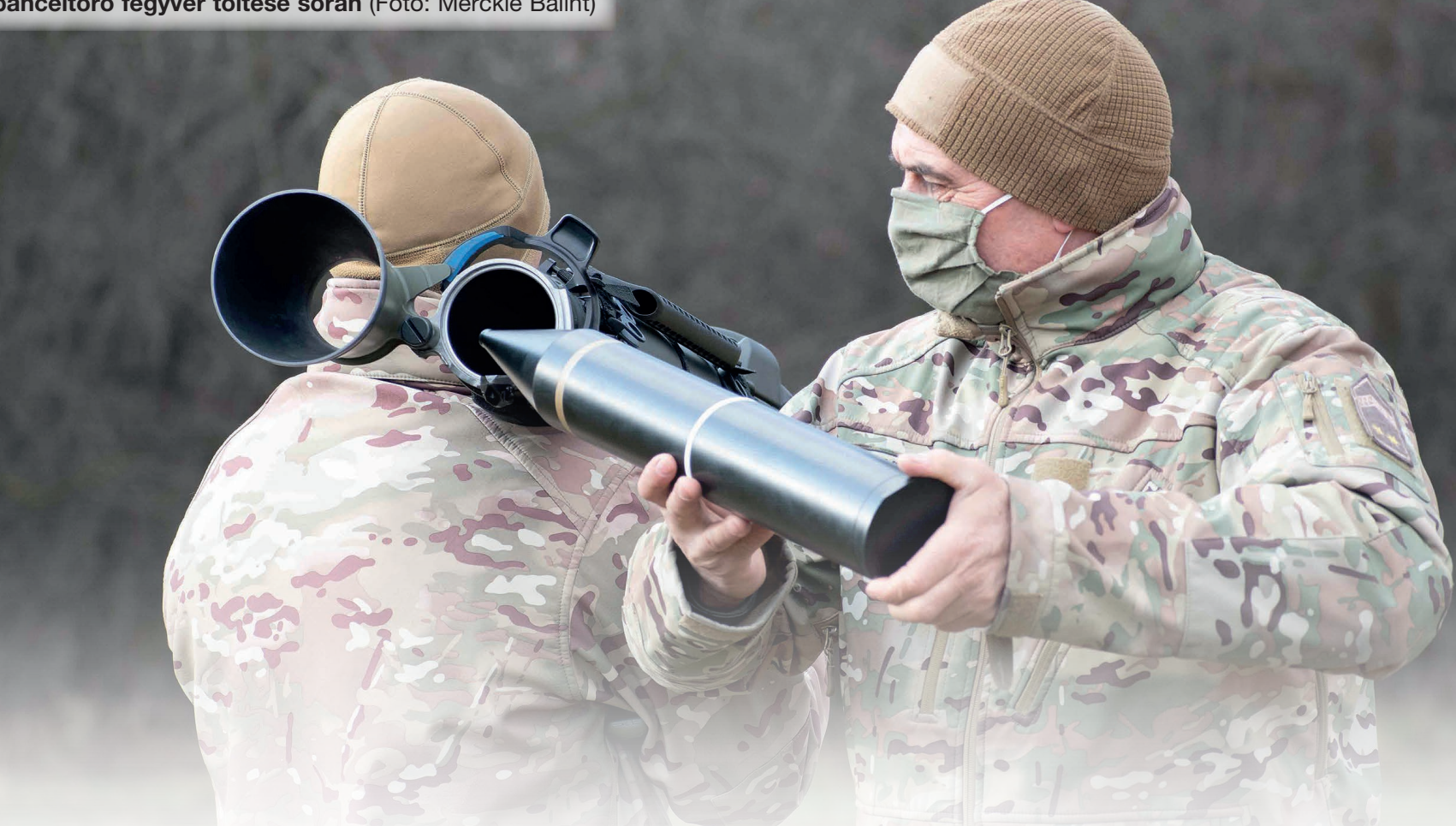

\title{
A Carl-Gustaf M4 típusú, többcélú hátrasiklás nélküli reaktív fegyver
}

A z eszközt Svédországban eredetileg harckocsik és páncélozott járművek leküzdésére fejlesztették ki, de az első példányok harctéri sikerei újabb és újabb változtatásokra ösztönözték a tervezőket, hogy a fegyver megfeleljen az egyre bonyolultabb követelményeknek, és így más jellegủ célok elleni harcra is alkalmassá váljon. A fegyverrendszer hatékonyságát, harci alkalmazhatóságát számos háborúban demonstrálta éles körülmények között is, így a lövészalakulatok és a különleges műveleti csoportok katonái olyan eszközhöz jutottak, amely „a harcterek mindeneseként" valóban többcélú eszköznek bizonyult. [1] Ennek köszönhető, hogy még napjainkban is folyamatosan növekszik azon haderő́k száma, amelyek rendszeresítik a típust, amelyből eddig 40-nél több ország vásárolt.

\section{A HÁTRASIKLÁS NÉLKÜLI KÉZI PÁNCÉLTÖRŐ FEGYVEREK}

A II. világháború során több haderőben használtak már kézi páncéltörő fegyvereket, amelyek a lövész alegységek katonái számára rövid lőtávolságon önálló páncéltörő képességet biztosítottak az ellenséges harcjárművekkel szemben. A legtöbb esetben rakétameghajtású gránátokat alkalmaztak, a svédek azonban más jellegü fegyverrel kísérleteztek. A hátrasiklás nélküli löveg (angolul: recoilless rifle) koncepcióját vették alapul, amely bizonyos elemeiben a rakétaindító eszközökhöz hasonlít, működési elve azonban jelentősen eltér attól. A fegyverből ugyanis egy módosított tüzérségi lőszert lőnek ki. A lőszert a töltényưrbe töltik be - amely egyben égőtér is -, de a csőfar nincs zárral
ÖSSZEFOGLALÁS: A Zrínyi Honvédelmi és Haderőfejlesztési Program részeként a Magyar Honvédség 2019-ben Carl-Gustaf M4 típusú hátrasiklás nélküli kézi páncéltörő fegyvereket szerzett be, amellyekkel új képességek birtokába jutottak a katonáink. A svéd hadiipar évtizedek óta gyárt különböző müködési elvü, hordozható páncéltörő eszközöket, amelyek egyik legsikeresebb típusa a 84 mm-es Carl-Gustaf M4 többcélú reaktív fegyver.

KULCSSZAVAK: Carl-Gustaf M4, páncéltörő fegyver, Zrínyi Honvédelmi és Haderőfejlesztési Program, reaktív fegyver
ABSTRACT: As part of the Zrínyi Defence and Armed Forces Development Program, in 2019 the Hungarian Armed Forces procured Carl-Gustaf M4 hand-held recoilless anti-tank weapons, with which our soldiers acquired new capabilities. The Swedish military industry has been manufacturing portable anti-tank devices with different operating principles for decades, one of the most successful types of which is the $84 \mathrm{~mm}$ Carl-Gustaf M4 multi-purpose reactive weapon.

KEY WORDS: Carl-Gustaf M4, anti-tank weapon, Zrínyi Defense and Armed Forces Development Program, reactive weapon 
lezárva, ahhoz egy belülről szűkülő keresztmetszetű, majd táguló Laval-fúvóka ${ }^{1}$ csatlakozik. A gránát hajítótöltete a lövéskor kiég, és a keletkező lőporgázok nem a lövegzárnak, hanem a Laval-fúvóka (a továbbiakban: csőfar) belső falának ütköznek, eközben ugyanakkora erőt fejtenek ki a lövedékre, mint a konfúzoron (szűkülő keresztmetszetű rész) és a diffúzoron (bővülő keresztmetszetű rész) keresztül a szabadba jutó gázok. A csőben az előre mozgó gránát, és a hátul kiáramló gáztömeg által keltett erők eredője közel egyenlő, vagyis a löveg csöve mozdulatlan marad, így a kezelőjét sem terheli hátralökő erő. [2]

A hátrasiklás nélküli lövegek alkalmazására több ország haderejében is megfogalmaztak távlati elképzeléseket. Az egyes nemzeteknél különböző űrméretű fegyvereket gyártottak, elsősorban páncéltörő feladatokra. 1966-ban hazánkban is hadrendbe állították a szovjet tervezésü SzPG-9D hordozható páncéltörő eszközöket, amelyeket Bulgáriából vásároltak. A '90-es években még használták a légimozgékonyságú, később gyorsreagálású zászlóaljnál, napjainkra azonban ezt a típusú löveget kivonták a Magyar Honvédség hadrendjéből. [3] A legtöbb ország haderejénél szintén így döntöttek, és a régebbi hátrasiklás nélküli lövegek helyett a kézi, és irányított páncéltörő rakétákat rendszeresítették. A 2011-ben kitört szíriai polgárháborúban azonban felbukkantak az egyszerűen kezelhető hátrasiklás nélküli lövegek, köztük olyan típusok is, amelyek ma már igazán kuriózumnak számítanak. [11] Az arab ország hadseregének arzenáljában előforduló a különböző hátrasiklás nélküli lövegek, között megtalálható volt a szovjet B-10-es, a már említett SzPG-9-es, a kínai 65-ös típus, az amerikai M40-es, a jugoszláv M60-as, és a brit L6-os.

\section{A Carl-Gustaf feJlesztése}

A svéd Bofors gyár szakemberei az 1940-es évek elején elkészítettek egy 20×180 R lőszerrel működő hátrasiklás nélküli kézifegyvert, amelyet kifejezetten a páncélozott jármúvek leküzdése érdekében fejlesztettek. A Pvg (Pansarvärnsgevär) $m / 42-e s$ volt az első ilyen elven müködő fegyver, amelyet egyetlen katona is hordozhatott. (2. ábra.) 14 kg-os tömegével jóval könnyebb volt, mint az akkor használt páncéltörő puskák, a kis ürméret azonban komolyan behatárolta képességeit. A 20 mm-es acélmagvas lövedék 100 m-es távolságban $40 \mathrm{~mm}$ vastagságú acéllemez átütésére volt képes, ami néhány évvel korábban még megfelelő átütőerőt képviselt volna, de a fejlesztés idején már egyre nagyobb védettségű harckocsikat gyártottak, amelyek ellen hatástalannak bizonyult. Mindössze 1000 példány készült belőle. [4]

A tervezők megkezdték egy nagyobb ürméretű fegyver fejlesztését, amelyből megfelelő hatású, kumulatív töltetű

\section{2. ábra. Pvg (Pansarvärnsgevär) M42-es hátrasiklás nélküli} kézifegyver és lőszerei [4]

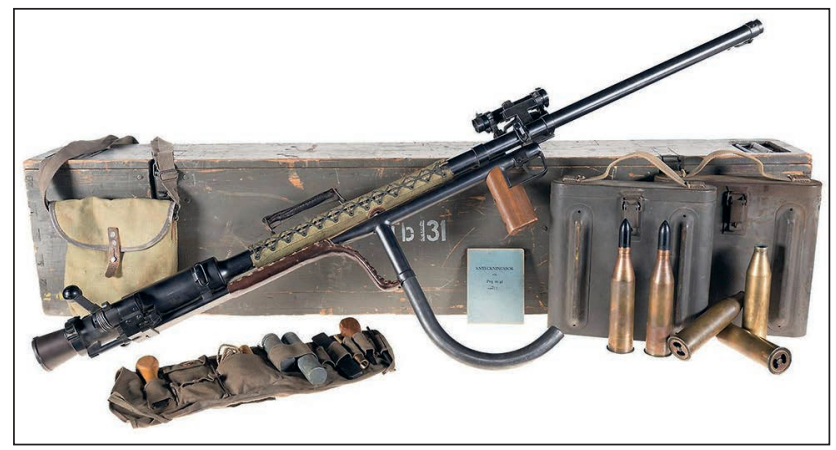

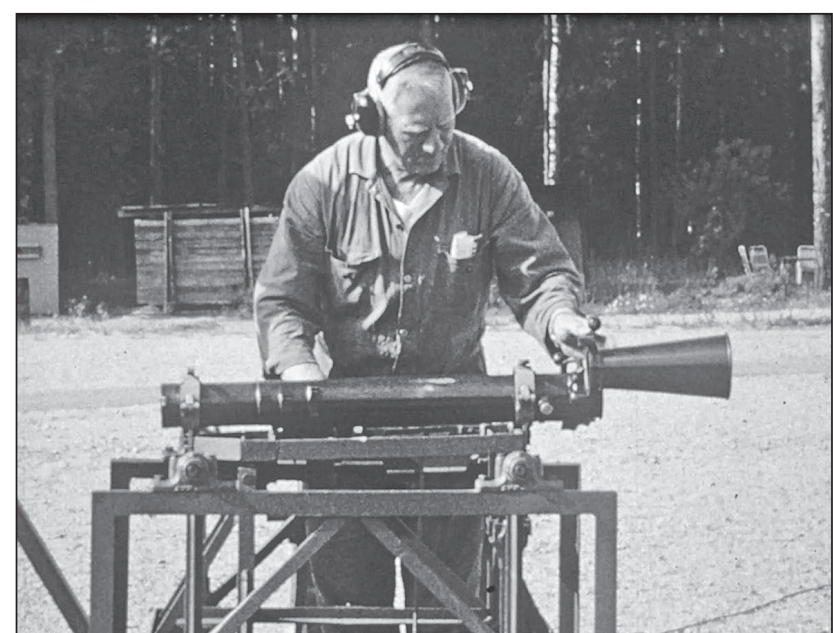

3. ábra. Lőkísérlet előkészítése az M48-as hátrasiklás nélküli fegyver egy korai változatával [7]

gránát lőhető ki, és így vastagabb páncélzat átütésére is képes. (3. ábra) A $84 \mathrm{~mm}$ belső átmérőjü prototípus 1946ban készült el. A fejlesztési munkák Harald Jentzen százados, Hugo Abramson és Sigfrid Akselson mérnökök nevéhez fűződnek. A fegyverhez $84 \times 246$ mm R lőszert terveztek.

Nem véletlenül választották ezt a kalibert, mert ilyen belső átmérőjű, huzagolt csövű ágyút már gyártottak korábban Svédországban. Az M/1894-06 típusjelű tüzérségi fegyvert erődökben telepítették, több évtizedig álltak hadrendben, a tervezők ezért nem változtattak a jól bevált 84 mm-es ürméreten.

A hadsereg által, az új hátrasiklás nélküli löveggel végzett lőkísérletek meggyőzték a döntéshozókat, így a fegyvert Grg m/48 (Grenatgefär model 1948) típusjellel rendszeresítették. A Carl-Gustaf típusnevet 1958-tól használják. Az elnevezés csak közvetve kapcsolódik X. Károly Gusztáv svéd királyhoz, hiszen a Bofors cég elődje, a Carl Gustaf Stads Gevärsfaktori² (Carl Gustaf Városi Fegyvergyár) volt, amelyet még 1812-ben alapítottak, Eskilstunában. A településnek az uralkodó különleges jogokat adott, emiatt említették sok helyen „a király városának”. [5]

\section{AZ M48 FEGYVER FÖBB JELLEMZŐ}

A Carl-Gustaf hátrasiklás nélküli löveg acélból készült, a tömege üresen $14 \mathrm{~kg}$, míg a hosszúsága $1130 \mathrm{~mm}$ volt. (4. ábra.) A 84 mm ürméretű huzagolt cső a gránátot forgásra kényszerítette, ilyen módon stabilizálva a röppályán. A gránát a torkolatot $290 \mathrm{~m} / \mathrm{s}$ sebességgel hagyta el. Ez a sebesség jóval több volt, mint a korabeli kézi páncéltörő rakétáké, hiszen a Bazooka változatok és az RPG-2-es rakétáinak sebessége ennek csak kevesebb, mint a fele volt.

A csövet elhagyva, a lövedék már nem gyorsult tovább, vagyis mint egy tüzérségi gránát repült a röppályán, a célzást ennek megfelelően kellett elvégezni. A hatásos lőtávolságot álló célok esetén 700 m-ben adták meg, mozgó jármúvek esetén csak 150-400 m távolságból lehetett az eszköz eredményes. A páncélátütő képessége is jóval több volt, mint más kézi páncéltörő fegyvereké, hiszen a kumulatív gránát megolvadó béléséből képződő fémsugár $400 \mathrm{~mm}$-es acéllemezen is képes volt áthatolni. Később a páncéltörő, és egyéb speciális feladatú gránátoknál rakétapóthajtást is alkalmaztak (RAP - Rocket-Assisted Projectile). Ilyen megoldással a kezdősebesség nem csökken, a hagyo- 
A töltés előtt a fegyver alsó részén a pisztolymarkolat mögött található felhúzókarral a rugó ellenében mozgó rudat a kezelő előre tolja. A rúd az első véghelyzetben megakad, ezzel az elsütő mechanizmus készen áll a tűzkiváltásra. Ezután a fegyvert bebiztosítva a markolat fölött található biztosítógomb jobbra nyomásával, majd a csőfart kinyitva a lőszer betölthető, és a csőfar visszazárható. A lövést a biztosítógomb balra nyomása után a pisztolymarkolat előtt elhelyezett elsütőbillentyűvel lehet kiváltani. Ekkor az elsütőrúd felszabadul, és hátrafelé indulva a mozgási energiáját mechanikusan átadja a töltényűr alatt található radiális irányban működő ütőszegnek, így az a lőszer hüvelyének oldalán elhelyezett csappantyúra üt. Az alumíniumhüvelyű lőszer talpát egy peremen felfekvő műanyag lemez zárja le, amely a tüzeléskor átszakad. A lövést követően az üres hüvelyt a csőfar nyitásával el kell távolítani. Az ürítést egy mechanizmus könnyíti meg, amelynek során a hüvely a csőfar zárókarjának segítségével részlegesen kihúzható a csőből. (5. ábra.)

A csövön helyezkedik el a mellső markolat, a válltámasz, valamint az állítható állványzat is, amely segítségével a fegyver tüzelés közben a földre támasztható. Az állítható állványzat $90^{\circ}$-kal elfordítható, így a fekvő tüzelési helyzetből az irányzó könnyen válthat térdelő, vagy álló testhelyzetre. (6. ábra.) A célzás alapvetően mechanikus irányzékkal történik, de már a korai változatnál megjelentek különböző nagyítású optikai eszközök is. A Carl-Gustaf M4 elődeinek tartozéka volt a hordheveder is, amelynek megtartása mellett, később a cső felső részén hordfogantyút alakítottak ki.

A segédirányzó katona fontos szerepet játszik a harcterület, és különösen a fegyver mögötti terület folyamatos figyelésben, új cél kiválasztásában, és egyben saját gépkarabélyával biztosítja társa tevékenységét. Egy fő is elegendő a fegyver kezeléséhez, ilyen esetben azonban a töltés bonyolultabb és hosszabb időt vesz igénybe, hiszen ehhez a kezelőnek le kell vennie a fegyvert a válláról. Összeszokott kezelőszemélyzet akár 6-10 célzott lövést is leadhat 1 perc alatt. lőszereket viszi magával, és hasonlóan a hagyományos tüzérségi lövegekhez, végrehajtja a töltést.

5. ábra. A 84 mm-es Carl-Gustaf M4 elsütőszerkezetének felépítése [18]

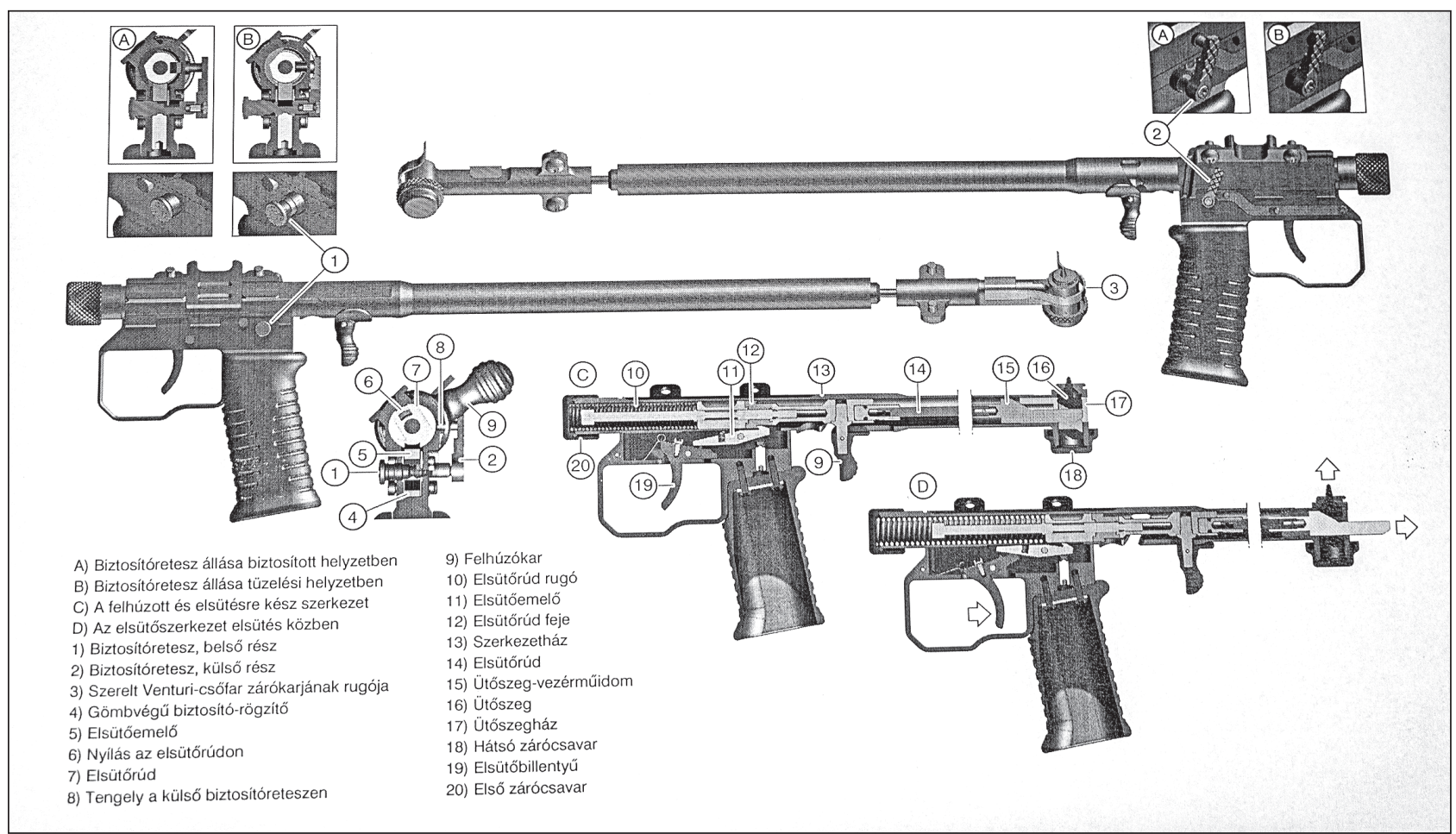




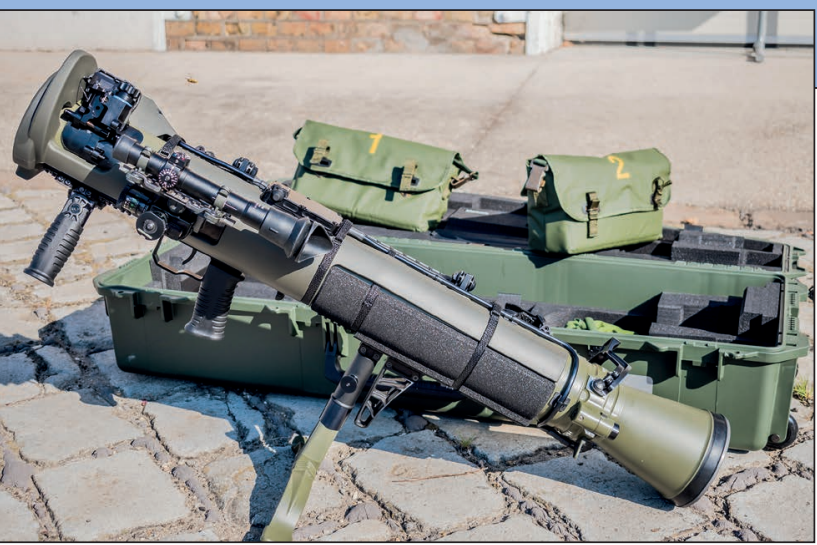

6. ábra. A 84 mm-es Carl-Gustaf M4 állványzatra helyezve (Fotó: Merckle Bálint)

A Carl-Gustaf fegyverrendszer müködési elve miatt a fegyver mögött jelentős az égésgázok kiáramlása, így a személyi sérülések és anyagi károk elkerülése érdekében a csőfartól 60 m-es távolságban, $45^{\circ}$-os nyílásszögű területen fokozott figyelmet kell fordítani a fegyver mögötti terület biztonságára. [6]

\section{AZ EXPORTSIKERT KÖVETŐ FEJLESZTÉSEK}

A svéd Bofors gyár hordozható fegyvere felkeltette más haderők figyelmét is, amelyek elsősorban a gránát nagy kezdősebessége és lőtávolsága miatt döntöttek a beszerzés mellett. A rakéta-póthajtás nélküli gránátok nagy kezdősebessége lehetővé tette, hogy rövidebb idő alatt érjék el a messzebb található célokat, mint a kézi páncéltörő rakéták. A fegyver páncélátütő képessége, robusztussága, egyszerű kezelhetősége, a kiképzésre fordítandó rövid időtartam és az eszköz megbízhatósága is mellette szólt.

A fegyvert - kisebb módosításokkal - Carl-Gustaf M2 típusjellel 1964 után kezdték exportra gyártani. Mindössze abban különbözött az M48-as típustól, hogy az acélcsövet megerősítették annak érdekében, hogy a nagy gáznyomást a svédországinál jóval melegebb éghajlaton, így Ausztráliában és Indiában is elviselje, de az eszköz méret- és tömegadatai megegyeztek az előd típuséival. Az M2-es exportsikereit követően, az eredeti változatra csak visszamenőleg kezdték használni az M1-es típusjelzést. Az M2-est több NATO-tagállamban rendszeresítették, így a szövetségi rendszer egyik elfogadott fegyverévé vált. A Carl-Gustafot a külföldi felhasználók sok esetben külön típusjellel, típusnévvel látták el.

Néhány évvel később kisebb változtatásokat végeztek a fegyveren. Ennek nyomán gyártották az M2-550-es altípust, amely minden lényeges paraméterében megegyezett

7. ábra. A lengyel hadsereg M3-asa egy magyarországi gyakorlaton (Fotó: Zsig Zoltán)

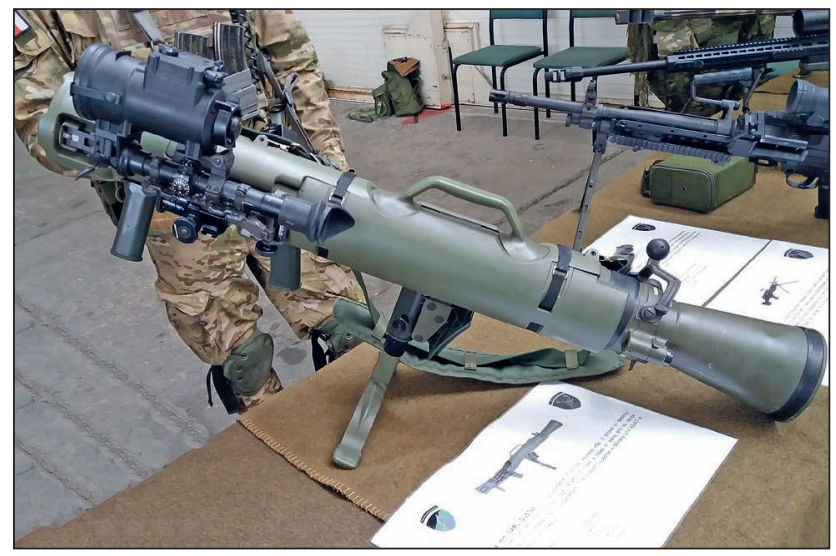

az M2-essel, de ehhez a változathoz már csatlakoztatható volt egy lézertávmérős célzókészülék is. Az azóta eltelt évek során - az újonnan felmerült igények miatt -, több lépcsőben jelentős módosításokat végeztek a fegyveren. Elsősorban méretének és tömegének csökkentését tartották szem előtt. A katonák kisebb méretű és tömegű fegyverre tartottak igényt, amelyet könnyebb gyalogmenet, futás, és harc közben hordozni. 1991-ben bemutatták az M3-as változatot, amely üvegszálerősítésű műanyag borítást kapott, így az acélcső vastagságát jelentősen csökkenthették, egyes pontokon mindössze 0,4 mm-re. Bizonyos helyeken alumíniumot is alkalmaztak, amely miatt a fegyver tömege $10 \mathrm{~kg}$-ra csökkent. A cső hosszát szintén redukálták, az 1065 mm-es érték némileg rövidebb lett az eredeti változat méretéhez képest.

Az M3-ast a svédeknél m/65-ös típusjelzéssel rendszeresítették, de sok más ország is megrendelte (7. ábra). Az Amerikai Egyesült Államok haderejénél az M3 MAAWS (Multirole Anti-Armor, Antipersonel Weapon System - többcélú páncéltörő és élőerő elleni fegyverrendszer) néven állították hadrendbe. Az afganisztáni háborúban, az AT4-es helyett - jóval nagyobb lőtávolsága miatt - egyre több példányt alkalmaztak. [7] [8] [12] [13]

\section{A LegúJABB, M4-ES változat}

A gyártó Bofors cég sok átalakításon ment keresztül az elmúlt évtizedekben. A hátrasiklás nélküli löveget előállító részleg 1999-ben a SAAB-hoz került. A Carl-Gustaf régi felhasználóitól újabb igény érkezett a fegyver méretének további csökkentésére, így már a SAAB Bofors Dynamics mérnökei egy még rövidebb és könnyebb változat kialakításán kezdtek dolgozni.

A Carl-Gustaf legújabb változatát, az M4-est 2014-ben mutatták be. Az M48-as 14 kg-os tömegéhez képest igazán figyelemre méltó az elért tömegcsökkenés, hiszen a fegyver tömege üresen mindössze $6,6 \mathrm{~kg}$ lett - vagyis kevesebb, mint a fele az eredeti Carl-Gustafnak - még az irányzékkal és az állvánnyal sem több 7 kg-nál. Mindezt úgy érték el, hogy az acélt gyakorlatilag teljesen mellőzték a konstrukcióból, a 24 huzaggal ellátott cső bélése, valamint a csőfar titánból készült. A hosszirányú terhelést a titánötvözet viseli, ám a sugár irányú terheléseket a csőre ragasztott karbonszálas borítás veszi fel. Az M4-es az M3ashoz képest is rövidebb lett, a különböző források ezt az adatot 950-990 mm közötti értékben adják meg. A gyártó nem közli a pontos méretet, azonban hangsúlyozza az 1 m-nél csekélyebb hosszúságot. [15] Az USA szárazföldi erejénél és a tengerészgyalogságánál az új változatot M3E1 jelzéssel állították hadrendbe. (1. táblázat) A kisebb és könnyebb Carl-Gustaf a korábbi változatoknál sokkal alkalmasabb a városi környezetben végrehajtott tevékenységre, és a harcjárművek belsejében is kevesebb helyet foglal el, így a személyzet számára egyszerübb lehet a kiés beszállás. Az új anyagok alkalmazása az élettartamra is

1. táblázat. A Carl-Gustaf változatok méret- és tömegadatainak összehasonlítása*

\begin{tabular}{|l|c|c|}
\hline \multicolumn{1}{|c|}{ Típusváltozat } & Hosszúság & Tömeg \\
\hline Grg m/48 (M1), M2 & $1130 \mathrm{~mm}$ & $14 \mathrm{~kg}$ \\
\hline M3 & $1065 \mathrm{~mm}$ & $10 \mathrm{~kg}$ \\
\hline M3E1, M4 & $950-990 \mathrm{~mm}$ & $6,6 \mathrm{~kg}$ \\
\hline
\end{tabular}

* (A szerző szerkesztése a [7] alapján) 


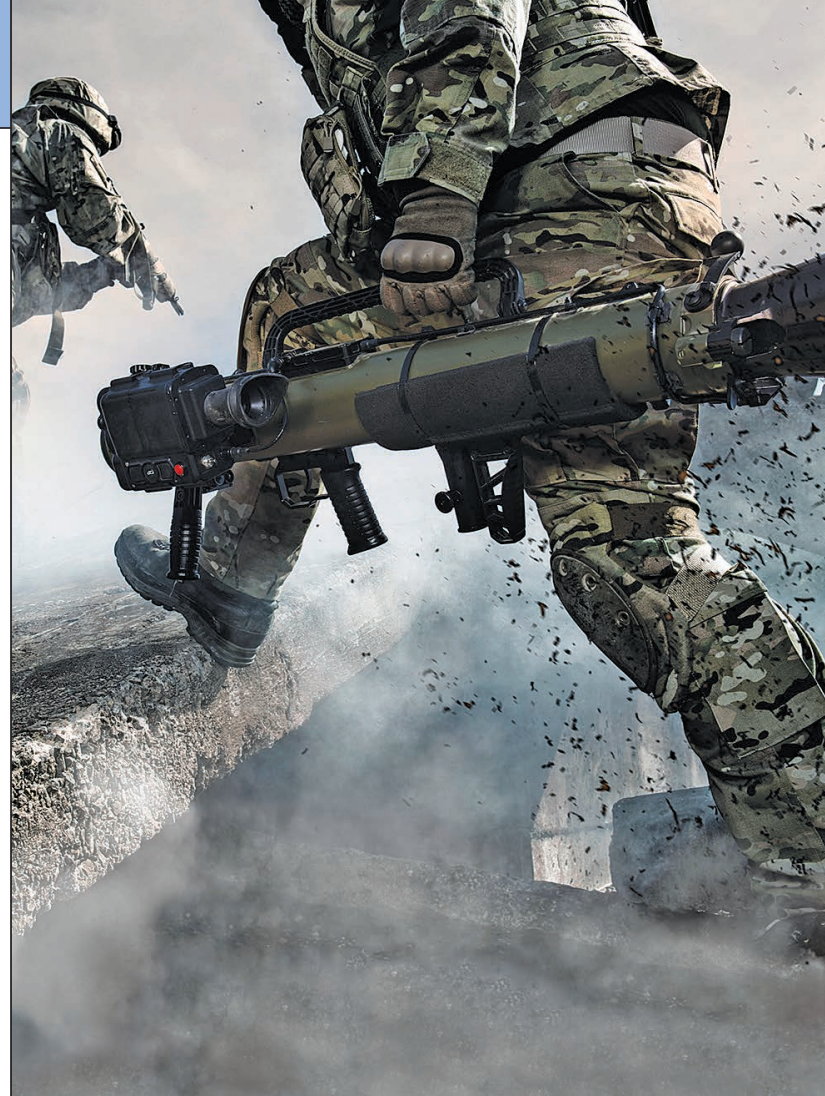

8. ábra. A Carl-Gustaf M4 hordhelyzetben [16]

kedvezően hatott, a csőfar például a korábbi változatnál 500 lövést viselt el, míg a legújabb változatnál - a titán alkalmazásának köszönhetően - már 1000-et. Az üzemeltetők az esedékes karbantartásokat, alkatrészcseréket beépített lövésszámláló értékei alapján ütemezhetik. Ez az eszköz csak a teljes töltettel végrehajtott lövéseket számolja, más esetben (például űrméret alatti gyakorló lőszer alkalmazásakor) nem számol. A lövésszámlálóhoz és a tűzvezető rendszerhez is csatlakoztatható táblagép, kezelői, valamint fegyvermesteri szinten lehetővé teszi a rögzített adatok kiolvasását. Az eszköz kialakítását az ergonómiai követelményeknek megfelelően szintén javították, állítható markolatot és válltámaszt kapott, az irányzékokhoz pedig sisakot, és fülhallgatót viselve is hozzá lehet férni. Az M4-es - ahogy a korábbi változat is - manuálisan (is) biztosítható, tehát töltött állapotban is hordozható. (8. ábra.) Kivételt jelentenek az Illum545, Illum545B és Smoke469 lőszerek, amelyeknél a töltött állapotban történő szállítás egyértelműen tilos. A gránátok célba juttatása érdekében, a Carl-Gustaf csövéhez - a gyártó kínálatában - továbbra is rendelkezésre áll a hagyományos mechanikus irányzék, mint másodlagos eszköz. A Picatinny-sín lehetővé teszi az irányzékok széles választékának alkalmazását. A standardnek tekinthető Telescopic Sight 557B elsődleges optikai irányzék helyett, különböző nagyítással rendelkező optikai eszközök szerelhetők fel. Ugyanez vonatkozik a vöröspontos irányzékok, az infravörös berendezések, valamint a hőkamerák alkalmazására is. [8]

\section{OKOSFEgYver}

A SAAB a Carl-Gustaf M4-est marketingjében már okosfegyverként hirdeti. Elsőként a szintén svéd Aimpoint cég FCS12-es intelligens berendezése miatt tartották jogosnak ezt a megnevezést. Azóta egy még modernebb változat, az FCS13RE termék is elérhető az eszközhöz, amely egy miniatürizált tűzvezető rendszer (Fire Control System). A gyártó többféle fegyverhez kínálja rendszerét, a menüpontok között beállítható, amikor a Carl-Gustaf M4-re

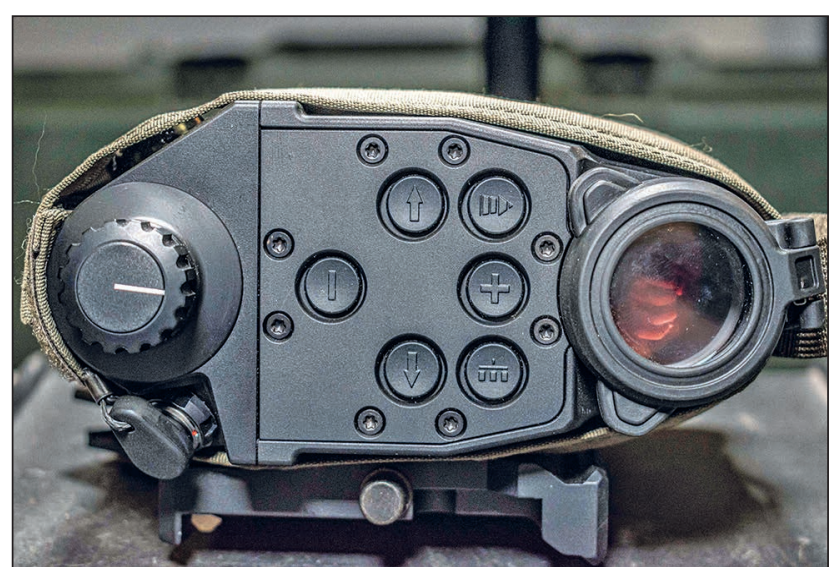

9. ábra. Az FCS13RE miniatürizált tứzvezető rendszer a Carl-Gustaf M4 fegyveren (Fotó: Merckle Bálint)

szerelik fel. Az Aimpont FCS13RE vízálló, kis mérete, valamint tömege miatt nem zavarja a kezelöt a fegyver hordozásában. Felszerelése az elsődleges irányzék helyére történhet. Az alumíniumházba épített rendszer hosszúsága $170 \mathrm{~mm}$, szélessége $76 \mathrm{~mm}$, magassága $157 \mathrm{~mm}$. (9. ábra.) A tömege, a működéshez szükséges $6 \mathrm{db}$ AA típusú elemmel együtt $1,6 \mathrm{~kg}$. Mivel az eszköz kompatibilis az infravörös éjjellátó berendezésekkel, ezért sötétben is használható. Beépített lézeres távolságmérővel rendelkezik. A nagy valószínűségű találathoz a cél távolsága az egyik legfontosabb adat, de a müszer emellett a többi információt (pl. a betöltött lőszer típusát és hőmérsékletét) szintén feldolgozza. Mindezek alapján a rendszer a reflexüvegre vetített vörös ponttal mutatja meg a kezelőnek, hogy hova kell céloznia. A számítógép az adott körülményekhez igazodva, az előre beprogramozott 50 különböző ballisztikai algoritmussal dolgozik. Az eszközön számos változó tényező beállítható, pl. megadható a terep dőlésszöge, és a rendszer figyelembe veszi a lőszer hajítótöltetének hőmérsékletét is. Szintén megadható az alkalmazott lőszer típusa, amelyhez igazodva a rendszer kidolgozza a célzás paramétereit. A lőszer állapotának érzékelését végző szenzor a töltényűrnél található, amelyhez egy adtatovábbító kábel vezet végig az M4-es csövén. A szenzor ezen keresztül kerül kapcsolatba az okos célzóberendezéssel. A kábelezés - amennyiben az alkalmazó nem kíván ilyen típusú célzórendszert alkalmazni a Carl-Gustaf M4-eshez - elhagyható. Az elsütőbillentyű elé egy kétgombos távvezérlő-egységre került, amely lehetővé teszi az irányzó számára, hogy célra tartás közben léptessen az intelligens irányzék menüjében, vagy opciókat válasszon ki. [14]

$A z$ elsődleges irányzék elé szerelhető norvég Vinghøg AS/Rheinmetall Defence KN250 Mk3 berendezés az éjjellátó képesség megteremtésével teszi lehetővé a fegyver éjszakai alkalmazását. [17] [18]

\section{LőSZEREK, ELTÉRŐ FELADATOKRA}

A Carl-Gustaf M4 többfeladatú reaktív fegyver, mert segítségével egymástól jelentősen eltérő célpontok, haditechnikai eszközök, épületek, vagy élőerő ellen is sikeresen alkalmazható, valamint harctámogató tevékenységre is alkalmas.

Eredetileg páncéltörő feladatokra tervezték, így elsődlegesen kumulatív gránátokat rendszeresítettek hozzá, de az elmúlt évtizedekben számos más működési elvű lőszert is kifejlesztettek, amelyeket különböző célok leküzdésére optimalizáltak. (10. ábra.) A 2,6 és 4,8 kg közötti tömeggel 


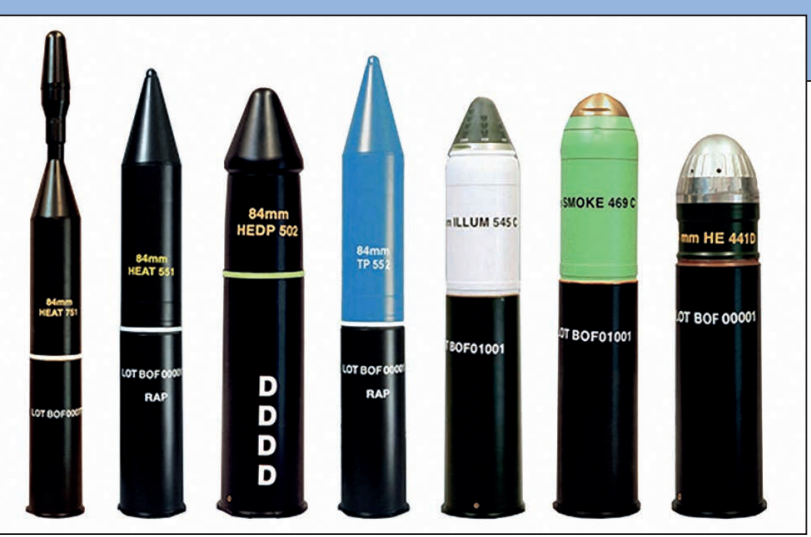

10. ábra. A Carl-Gustaf M4 84 mm-es fegyverből tüzelhető egyes gránáttípusok [18]

rendelkező gránátok szállításbiztosítóval rendelkeznek, ugyanakkor gumisapkával is védik őket a külső behatásoktól. Robbanótöltetük csak a lövést követően, a csövet elhagyva élesedik. Az élesítéshez a huzagolás okozta forgást és a gránátok gyorsulásából adódó erőhatásokat használják ki. Az élesedési távolság gránátonként változó, változattól függően $5 \mathrm{~m}$ és $85 \mathrm{~m}$ között van. [7]

\section{HEAT 551 (HIGH EXPLOSIVE ANTI TANK)}

A páncélozott célok elleni harcra tervezett megbízható és hatékony kumulatív töltetű gránát a páncélozott járművek kb. 90\%-a ellen hatásos mintegy 700 m-es hatótávolságon belül. Alkalmazható betonbunkerek és leszálló légi jármüvek ellen is. Nagy áthatoló képessége mellett a gránát repeszei is komoly pusztító hatást gyakorolnak a célpont közvetlen közelében lévő eszközökre és személyekre. A rakéta tömege $3,1 \mathrm{~kg}$, a póthajtásnak köszönhetően a röppálya lapos, a cél eléréséig a repülési idő rövid.

\section{HEAT 551C RS (REDUCED SENSITIVITY)}

Szintén kumulatív hatású, de csökkentett érzékenységű gránát, amelynek csúcsán egy rúd található. Ez segít abban, hogy ideális körülmények között alakulhasson ki a kumulatív hatás. A robbanótöltet működésbe lépése után a megolvadó béléskúpból a plazma állapotú fémsugár átüti a páncélzatot. A gránát rakéta-póthajtással rendelkezik.

\section{HEAT 751}

Természetesen a svéd mérnökök figyelmét sem kerülte el az a tény, hogy az utóbbi évtizedekben egyre több országban állítottak hadrendbe reaktív páncélzattal felszerelt harckocsikat. Ezek ellen csak a tandem robbanófejes gránát hatásos. A $84 \mathrm{~mm}$-es, kettős fejrésszel rendelkező HEAT 751-es az első robbanással semlegesíti a reaktív védőelemet (ERA - Explosive Reactive Armour - robbanó reaktív páncél), majd a másodikkal, a főtöltettel a jármü páncélzatát támadja. A kumulatív fej $500 \mathrm{~mm}$-es acéllemezt képes így átütni a reaktív páncélelem mögött. $A z$ össztömege $3,8 \mathrm{~kg}$, ebből $0,4 \mathrm{~kg}$ a hajítótöltet, a gránát maga $2,9 \mathrm{~kg}$, amelyből $1,5 \mathrm{~kg}$ a robbanótöltet. A csövet elhagyva kis méretű vezérsíkok nyílnak ki a gránátból, de rakéta-póthajtással is rendelkezik.

\section{HEAT 655 CS (CONFINED SPACE)}

A Carl-Gustaf hátránya, hogy a lövéskor hátul kiáramló gázok miatt nem, vagy csak korlátozottan alkalmazható zárt helyiségböl. Azonban városi környezetben is szükség lehet a fegyverre, ezért fejlesztették ki a 84 mm-es HEAT 655 CS gránátot, amely biztonságosan kilőhető épületek ablakaiból is, erre utal az utolsó két betű (SC:

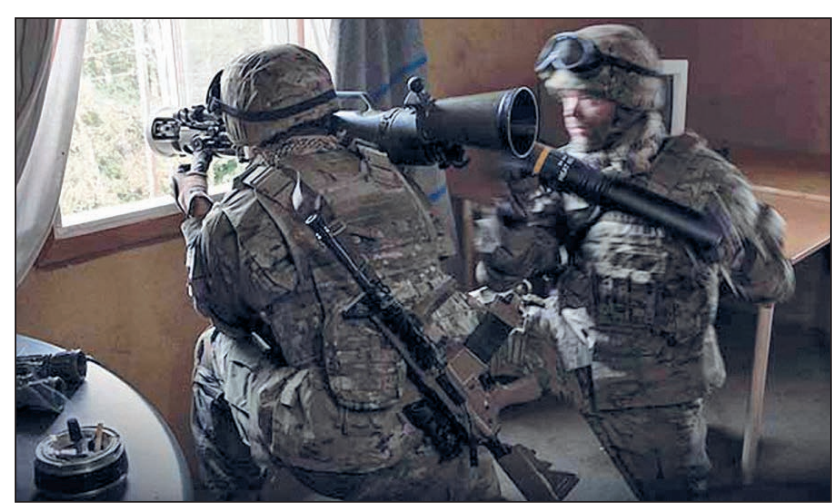

11. ábra. Egy Carl-Gustaf M3-as fegyverbe HEAT 655 CS

lőszert töltenek épület ablakából leadott lövést megelőzően [17]

Confined Space - korlátozott hely). (11. ábra.) A lőszer hajítótöltete mögött elhelyezett speciális anyag felfogja és csökkenti a kiáramló gázok hatásait. A harci járművek minden típusa ellen bevethető, nagy pusztító erejü, kumulatív robbanófejjel felszerelt eszköz, amely például bunkerek, páncélozatlan és páncélozott járművek megsemmisítésére is használható. Egy másik speciális technológiai megoldást is alkalmaztak ennél a gránátnál. A robbanótöltet előtti béléskúp bimetál szerkezetű, vagyis két különböző fémből készült. Az egyik a megszokott módon átégeti a gyári adatok szerint $500 \mathrm{~mm}$-es hengerelt acéllemezt is, a másik pedig a harcjármű belsejében további pusztító hatást fejt ki.

\section{HEDP 502 (High EXPLosive Dual PuRPose)}

A hagyományos páncéltörő gránátok is képesek behatolni épületekbe, odabent azonban aránylag kevés kárt okoznak. A 84 mm-es, kettős rendeltetésü típust arra fejlesztettek ki, hogy a falak között megbúvó ellenséges erők ellen is hatékonyan alkalmazható legyen, de páncélozott jármüvek leküzdésére is bevethető.

Az eltérő célok leküzdését úgy oldották meg, hogy az adott körülményeknek megfelelően kiválasztva késleltethetik a gyújtást, amelyet egyszerű módon lehet beálítani. A gránát ugyanis két külön csappantyúval rendelkezik, átellenes oldalain egy-egy db található. Az egyik oldalán az azonnali robbanás üzemmódot kiváltó csappantyúnál az angol Impact (becsapódás) szóra utaló I betű, a másik oldalán a Delay (késleltetés) D betű került felfestésre. A gránátot a felfestett jelzés alapján annak megfelelően töltik be a csőbe, amelyik hatására éppen szükség van. Páncélozott jármű esetén a lövedék a becsapódáskor azonnal robban, és 150 mm vastagságú acélt képes átütni. A másik beállítás szerint a gránát épület falához csapódva érzékeli a lassulást, és késleltetve lép működésbe.

\section{ASM 509 (ANTI-StruCtURES MUNITION)}

A gránátot kifejezetten az épületekben megbúvó élőerő leküzdése fejlesztették. Ennél a töltettípusnál is két eltérő gyújtási mód - azonnali, és késleltetett - beállítása lehetséges. Szintén I és D betűk segítik a feladatnak megfelelően a csőbe helyezést. Páncélzat ellen nem alkalmazható, csak falak átütésére képes.

\section{MT 756 (Multi TARGet)}

A több célpont elleni gránát, valójában kifejezetten vastag falú, téglából, betonból készült bunkerek rombolására vethető be. Ehhez speciális kialakításra volt szükség, így egy 
nagy méretű, buborékszerű részt alakítottak ki a gránát csúcsán, ez a fallal történő érintkezéskor felrobban, lyukat üt rajta, majd a fő rész behatol, és a második töltet már bent fejti ki pusztító hatását. A rakéta-póthajtású gránát a cél méretétől függően 300-600 m-ig hatásos.

\section{HE 441D}

Páncélzat nélküli járművek, vagy élőerő ellen alkalmazható gránát, amelynél szintén megválasztható, hogy a gyújtószerkezet becsapódáskor, vagy időzítve robbanjon fel. Az utóbbi módnál a töltés előtt a fejet elforgatva beállítható a kívánt késleltetési idő, így a levegőben robban fel a töltet, a meghatározott távolságban. A gránát $800 \mathrm{db}$ kis méretű fémgolyóval fejti ki pusztító hatását. Mivel a becsapódási szög nem releváns, ezért 1200 m-ig hatékonyan alkalmazható.

\section{ADM 401 (AREa Defence Munition)}

Területvédelmi gránát, amely szabadban lévő, vagyis nem fedezékben megbúvó élőerő ellen alkalmazható. Bevetésével visszaverhető, vagy megállítható egy gyalogsági támadás. A lövedék 1100 db kis méretű nyilat lövell szét nagy területen, ezzel érik el a kívánt hatást. A kiszórást nem robbanóanyag, hanem a hajtóanyag égése során keletkező nagynyomású gáz végzi el, a gránátnak gyújtószerkezete sincs.

\section{SMOKE 469C}

A 84 mm-es SMOKE 469C füstképző gránát számos harcászati szituációban alkalmazható. A különféle bevetési lehetőségek közül kiemelendő az álcázás, a vakítás és a felderítés. A gránátot 1300 m-es távolságig kilőve, az álcázás füstköd létrehozásával valósul meg. Az ellenség és a saját pozíció között keletkező füst a saját erők támadását, vagy visszavonulását álcázhatja. Felderítés során a csapat más egységeket is támogathat a célpontok kijelölésével. Végül, ha az eszközt közvetlenül a célra irányítják, azzal lehetővé válik az ellenség elvakítása. Az eszköz használata lehetővé teszi az alegységek számára a rövid időn belüli, 10-15 m szélességű füstködfüggöny alkalmazását.

\section{ILLUM 454C}

Éjszakai műveletek világító gránát segítségével is támogathatók. A kilőtt és ballisztikus pályán magasba emelkedett gránát a levegőben kis ejtőernyőt nyit, így $5 \mathrm{~m} / \mathrm{s}$ sebességgel ereszkedve 30 másodpercig 650000 kandela erősségü fényt bocsát ki, ezzel 4-500 m átmérőjü területet világítva meg. A Carl-Gustaf csövének emelkedési szögétől függően 300-2100 m-ig lőhető ki.

\section{A KIKÉPZÉST SEGíTŐ ESZKÖZÖK ÉS LÖSZEREK}

A fegyver megfelelő kezelésének oktatása éles gránátokkal végzett lövészetek nélkül is elvégezhető, amely ily módon biztonságosabb és gazdaságosabb. Több lehetőség is rendelkezésre áll a helyes célzás gyakorlására. Két betétcső helyezhető el a fegyverben, a 7,62 mm Sub-Calibre 553B (ürméret alatti) típusból 7,62 × $51 \mathrm{~mm}$-es puskalőszert lehet kilőni. (12. ábra.) A típusjel nélküli 20 mm-es Sub Calibre betétcsőből pedig a katonák még nagyobb lőszerrel gyakorolhatják a célzást, és a tűzkiváltást.

A hátrasiklás nélküli fegyverből történő gyakorló lövéshez is készítettek különböző lőszereket, amelyekkel költ-

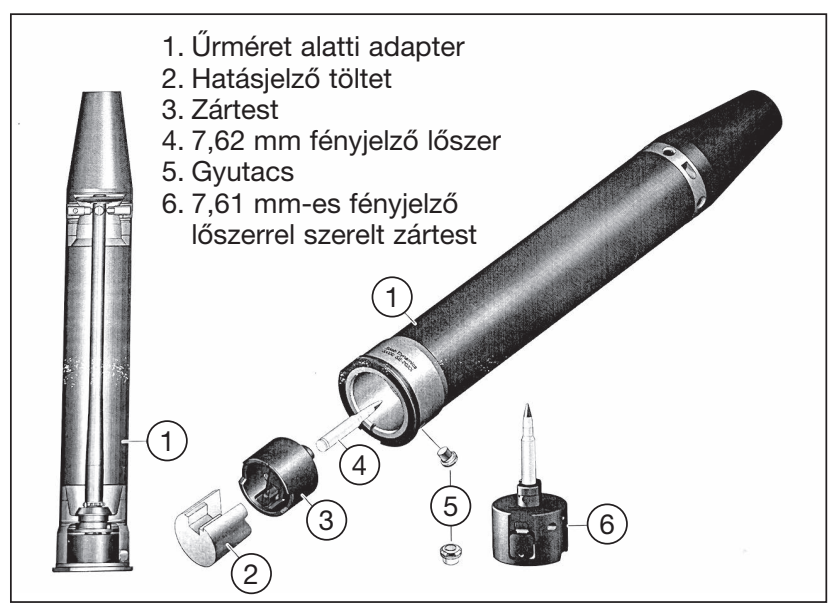

12. ábra. Az 553B ürméret alatti gyakorló lőszer szerkezeti felépítése [18]

séghatékonyabban végezhető a kiképzés, mint a harci típusokkal.

A TPT 141 (Training Practice Tracer) már „valódi” gránát, amelyre a magyarul a „Iőtéri” megnevezést használhatjuk, mivel robbanótöltetet nem tartalmaz. Fényjelzőjének köszönhetően megfigyelhető a röppálya és a becsapódás, ezek alapján ellenőrizhető, mennyire volt helyes a célzás.

A TP 552 (Training Paractice) szintén lőtéri gránát, a fő különbség az, hogy rakétahajtóműve miatt a RAP-lőszerek használatának gyakorlására alkalmas.

A SAAB cég Carl-Gustaf WES (Weapon Effect Simulator) néven gyárt egy elektronikus, lézersugárzást kibocsátó berendezést, amely a harchelyzetek élethű szimulálására képes. Az eszközzel virtuális módon sajátítható el a fegyver kezelése.

\section{A FEgYVER ÉRTÉKELÉSE}

A svéd gyár szakemberei a fent ismertetett lőszerek miatt hirdetik a Carl-Gustaf M4-et sokoldalúbbnak a hasonló tulajdonsággal rendelkező más fegyvereknél. Egyértelműen a többcélú felhasználhatóságot emelik ki, amelynek révén a Carl-Gustaf M4 eltérő jellegű célok leküzdésére vethető be, ráadásul egyes esetekben nagyobb távolságban, mint más, kézi páncéltörő rakétákat. (Az igazság kedvéért megemlítendő, hogy a régi RPG-7-eshez is elérhető már tandem robbanótöltetű, termobárikus, és repeszromboló rakéta.) Kijelenthető, hogy napjainkban más hordozható, reaktív fegyverhez nem tartozik ilyen nagy, eltérő feladatra szánt lőszerválaszték. A gyalogos katonák természetesen csak korlátozott mennyiségü gránátot vihetnek magukkal, vagyis fel kell készülniük arra, hogy milyen célokkal kerülhetnek szembe. Amennyiben szállítójárművel utaznak, akkor valóban nagyobb javadalmazást és szélesebb lőszerválasztékot málházhatnak a harcfeladatra.

\section{TovÁBBI FEJLESZTÉSEK}

A Carl-Gustaf fejlesztése nem állt meg, napjainkban olyan kísérleteket folytatnak, amelynek nyomán teljesen új kategóriába sorolható lesz a fegyver. A svéd gyártó ugyanis elhatározta, hogy precizitásban még egy fokozattal előrébb lépnek. A SAAB az amerikai Raeython céggel már közösen dolgozik egy félaktív, lézeres irányítású lövedék fejlesztésén. A munkák során komoly eredményeket értek el. Az új 
GCGM (Guided Carl-Gustaf Munition) gránátból egy 2019 szeptemberében rendezett éleslövészeten több darabot is kipróbáltak. A svédországi és amerikai lőtereken elvégzett tesztek során az M3E1-es változatú fegyvert állványra szerelték, ebből lőtték ki a gránátokat álló és mozgó célokra, amelyeket sikeresen eltaláltak. A hatásos lőtávolság is megnövekedett, a rakéta póthajtásnak köszönhetően 2000 m-ig képesek a célok megsemmisítésére. A célmegjelölő készüléket a fegyver csövére erősítették. A gránát irányítását röppályán a késpenge alakú vezérsíkok teszik lehetővé, amelyek a csövet elhagyva nyílnak ki. A nyilvánosságra hozott fényképeken a gránát már inkább egy irányított páncéltörő rakétára emlékeztet; mérete és tömege az új vezérlőrendszer és a hajtómű miatt megnövekedett.

További más vezérlési módok kipróbálását is tervezik, így szóba jöhet többek közt az infravörös önirányítás lehetősége is, amely lehetővé teszi a „fire and forget” (tüzelj és felejsd el) módszer alkalmazását. [8] [16]

\section{ÖSSZEGZÉS}

A Carl-Gustaf M4 modell a SAAB korábbi sikerének, az M3-asnak a korszerűsített változata, amelynek speciális kialakítása flexibilitást biztosít a felhasználók számára. Méretét tekintve kisebb, letisztultabb kialakítású, mint elődei. A kisebb méret nemcsak a könnyebb hordozhatóság miatt előnyös, hanem a napjainkban megváltozott hercterek (pl. városi terep) okozta kihívásokra is nyújt megoldást. A kisebb tömeget könnyebb alkatrészek használatával, az acél alkatrészek titánra váltásával és szénszálas megerősítéssel érték el. A fegyver működési rugalmassága és precizitása valóban erőteljes kombináció.

A fegyverrendszer - Zrínyi Honvédelmi és Haderőfejlesztési Program keretében történt - beszerzése révén a Magyar Honvédség olyan képességeket szerez, amelyek hozzájárulnak a haderő alapvető modernizációjához, ütőképességének fokozásához.

\section{HIVATKOZOTT FORRÁSOK}

[1] Nagy István György, Szentesi György. Arzenál '82 Budapest: Zrínyi, 1982, 150. o.;

[2] Műszaki leírás a 84 mm-es RCL Carl-Gustaf M4-hez SAAB Dynamics AB 301398794-1. 1. kiadás;

[3] Gáspár Tibor. „Fejezetek a Fegyverzeti Szolgálat és jogelődei történetébőL IV. rész." Katonai Logisztika 21. évf. 1. sz. (2013.): 88-153 o. http://epa.oszk. hu/02700/02735/00075/pdf/EPA02735_katonai_logisztika_2013_1_088-153.pdf;

[4] Modern Firearms. „Carl Gustav m/42”, 2010. október 27. https://modernfirearms.net/en/anti-tank-rifles/ sweden-anti-tank-rifles/carl-gustav-m42-eng/;

[5] „Carl Gustafs stads gevärsfaktori” Eskilstuna kommun. Elérés 2021. január 6. https://www. eskilstuna.se/uppleva-och-gora/bibliotek-arkiv-ochlokalhistoria/lokalhistoria---eskilskallan/sok-i-arkiv/ historiska-artiklar/industrihistoria/carl-gustafs-stadsgevarsfaktori.html;

[6] Miliray factory.com „Carl-Gustav M4 (CGM4) Man-Portable, Shoulder-Fired Multi-role Weapon" https://www.militaryfactory.com/smallarms/detail. asp?smallarms_id=976;

[7] Start. „A Battleground Hero”. Elérés 2021. január 6. https://www.saab.com/newsroom/stories/2020/ april/a-battleground-hero;
[8] Beneda Károly Tamás. Repülőgép-hajtóművek elmélete II. >3. Fúvócsövek >3.3. Laval-csövek alkalmazása Akadémiai Kiadó.

DOI: 10.1556/9789634542865 Online megjelenés éve: https://mersz.hu/dokumentum/m416rhe2 18 Letöltés: 2020.11.20;

[9] Pokorádi László. Áramlástan. Elektronikus jegyzet. Debrecen, 2002 http://uni-obuda.hu/users/pokoradi. laszlo/aramlastan.pdf;

[10] „Ancient U.S. Weapon Makes a Surprise Reappearance in Syria”. Wired. Elérés 2021. január 6. https://www.wired.com/2013/05/ancient-us-weaponin-syria/;

[11] „SVERIGE MALL”. Elérés 2021. január 6. http://www.gotavapen.se/gota/artiklar/rifles_se/pvg/ at_rifles_se.htm;

[12] Modern Firearms. „Carl-Gustaf”, 2010. október 28. https://modernfirearms.net/en/grenade-launchers/ sweden-grenade-launchers/carl-gustaf-eng/;

[13] Defense Media Network. „SOCOM Seeks Lighter Carl Gustaf”. Elérés 2021. január 6. https://www.defensemedianetwork.com/stories/ socom-seeks-lighter-carl-gustaf/;

[14] „Aimpoint® FCS13RE”. Elérés 2021. január 6. https://www.aimpoint.com/product/aimpointfcs 13re/?tx_pxaproductmanager_pi1\%5Bcategory_0 $\% 5 \mathrm{D}=13 \& \mathrm{cHash}=97 \mathrm{ee} 71452 \mathrm{c} 7893 \mathrm{cef54244d2fa8c0}$ b0b, https://www.aimpoint.com/product/aimpointfcs13re/;

[15] Vinghog KN250 Mk3 Éjjellátó Operating Manuall Rheinmetall P3388E 850-813257 Rev.C.;

[16] https://www.defenseworld.net/news/27069/ Latvia_Estonia_order_Carl_Gustaf_M4_Anti_tank_ Weapon_from_Saab\#.YBPYIOhKiUI Letöltés: 2020.03.15.;

[17] Small Arms Defense Journal. THE NEW CARLGUSTAF M4: LIGHTER-BETTER-SMARTER. http://www.sadefensejournal.com/wp/the-new-carlgustaf-m4-lighter-better-smarter/ Letöltés: 2020.03.15.;

[18] https://wes.feridajardasti.fun/84mm-rl-heat-round. html Letöltés: 2021.02.15.

\section{JEGYZETEK}

1 Magyarországon a korábbi szakirodalmi forrásokban a „Lavalfúvóka" meghatározást alkalmazták a hátrasiklás nélküli löveg szűkülö-bővülő szekciójának megnevezésekor, míg az angol nyelvű irodalomban a Venturi-cső megnevezés terjedt el. Mindkettő hasonló kialakítású, de a Laval-fúvókánál a kiáramló gázok sebességének felgyorsítása a cél, a legszűkebb átmérőt is ehhez méretezik. Maga a Venturi-cső egy szűkülő csőszakaszból (konfúzorból) és egy bővülő csőszakaszból (diffúzorból) áll. Amikor a Laval-cső körüli környezeti nyomás nem sokkal kisebb a fúvócső bemenô nyomásánál, akkor Venturi-csőként üzemel, vagyis a legszükebb keresztmetszetig gyorsuló szubszonikus áramlást biztosít, amely a torok után visszalassul, ahogy azt a diffúzoros szakasz diktálja. A torokkeresztmetszeten túl megindul ugyan a szuperszonikus expanzió a nyomás csökkenésével, de abban a pillanatban létrejön egy merőleges lökéshullám (először a fúvócsőben), amikor a belőle következő nyomáslefutás éppen a környezetbe történő expanziót hozza létre. [9] [10]

2 A svéd gyár egyes ismétlőpuskáinak és M45-ös típusjelú géppisztolyának szintén a Carl-Gustaf nevet adták, így vált ismertté a külföldi felhasználóknál. Ezért a típusnév félreértésre adhat okot. 